\title{
Effects of preconditioning and extrusion of linseed on the ruminal biohydrogenation of fatty acids. 1. In vivo studies
}

\author{
Fowad AKRAIM ${ }^{\mathrm{a}}$, Marie-Claude NICOT ${ }^{\mathrm{a}}$, Pierre WEILL $^{\mathrm{b}}$, \\ Francis ENJALBERT ${ }^{\mathrm{a} *}$ \\ a École Nationale Vétérinaire, Laboratoire de Nutrition, 23 chemin des Capelles, BP 87614, \\ 31076 Toulouse Cedex 3, France \\ ${ }^{\mathrm{b}}$ Valorex, 7 La Messayais, 35210 Combourtillé, France
}

(Received 6 January 2005 - Accepted 12 December 2005)

\begin{abstract}
The extent and intermediates of ruminal biohydrogenation (BH) of fatty acids (FA) from a blend of linseed and wheat bran (70:30) were investigated in the rumen fluid, rumen particle phase and duodenal flow. The blend was ground through a $3 \mathrm{~mm}$ screen and used raw or extruded, or was ground through a $6 \mathrm{~mm}$ screen and preconditioned. Three dry Holstein cows fitted with ruminal and duodenal cannulas were used in a $3 \times 3$ Latin square design, with 18 days adaptation. The diet contained 20\% (DM basis) of the linseed based blend. Twelve samples taken over 3 days were composited for analysis of rumen fluid, rumen particle phase and duodenal flow. The BH of FA from linseed resulted in the appearance of a great number of C18:1 intermediates, among which trans-10+11 to trans-16C18:1 were the most abundant. The proportion of cis-9,trans-11C18:2 was low. Preconditioning coarsely ground linseed resulted in a lower extent of $\mathrm{C} 18: 2$ and $\mathrm{C} 18: 3 \mathrm{BH}$, and lower proportions of trans-12 to trans-16C18:1 intermediates than extrusion or a lack of processing of finely ground linseed. On the contrary, extrusion did not affect the extent of $\mathrm{BH}$ and had no significant effect on the proportions of trans-C18:1 intermediates, but increased the proportion of cis-9,trans-11C18:2 in both rumen phases. Different digesta types resulted in different estimates of $\mathrm{BH}$. The extent of $\mathrm{BH}$ and the proportions of trans-C18:1 intermediates were lower in the rumen particle phase and higher in the rumen fluid than in the duodenum. Moreover, interactions between digesta type and treatment of linseed were observed.
\end{abstract}

biohydrogenation / linseed / preconditioning / extrusion

Résumé - Effets du préconditionnement et de l'extrusion de la graine de lin sur la biohydrogénation ruminale des acides gras. 1. Études in vivo. L'importance et les intermédiaires de la biohydrogénation ruminale $(\mathrm{BH})$ des acides gras d'un mélange lin / son (70:30) ont été étudiés dans les phases solide et liquide du rumen et dans le contenu duodénal. Le mélange à base de lin

\footnotetext{
*Corresponding author: f.enjalbert@envt.fr
} 
était broyé à la grille de $3 \mathrm{~mm}$ et utilisé cru ou extrudé, ou broyé à la grille de $6 \mathrm{~mm}$ et préconditionné. Trois vaches Holstein taries, équipées de canules ruminale et duodénale, ont été utilisées dans un protocole en carré latin $3 \times 3$, avec 18 jours d'adaptation par période. La ration contenait $20 \%$ (par rapport à la matière sèche) de mélange à base de lin. Douze échantillons de phases solide et liquide du rumen et de contenu duodénal, ont été prélevés sur 3 jours et mélangés avant analyse. La BH des acides gras du lin a conduit à l'apparition d'un grand nombre d'intermédiaires C18:1trans, parmi lesquels les trans-10+11 à trans-16 étaient les plus abondants. La proportion de C18:2cis-9,trans-11 était faible. Le préconditionnement du mélange grossièrement broyé a conduit à une $\mathrm{BH}$ de $\mathrm{C} 18: 2$ et $\mathrm{C} 18: 3$ et des proportions de $\mathrm{C} 18: 1$ trans-12 à trans-16 plus faibles que l'extrusion ou l'absence de traitement de mélange finement broyé. Au contraire, l'extrusion n'a pas modifié l'importance de la $\mathrm{BH}$ ou les proportions de C18:1trans, mais a augmenté la proportion de C18:2cis-9,trans-11 dans le rumen. Les différents types de prélèvement ont conduit à différentes estimations de la BH. L'importance de la BH et les proportions d'intermédiaires trans-C18:1 étaient plus faibles dans la phase solide et plus élevées dans la phase liquide du rumen que dans le contenu duodénal. En outre, des interactions entre type de digesta et traitement du lin ont été observées.

biohydrogénation / lin / préconditionnement / extrusion

\section{INTRODUCTION}

Adding fat to ruminant rations increases the energy density of the diet [22] and, when unsaturated fatty acids (FA) are used, improves the nutritional quality of milk fat [24] and meat [12,29] by decreasing the ratio of saturated to unsaturated FA. The use of dietary fat with polyunsaturated FA (PUFA) can result in the enrichment of products with FA that have positive effects on the consumer's health $[24,36]$, and if $\mathrm{C} 18: 3$ is fed to cows via linseed, to a decreased n-6/n-3 polyunsaturated FA ratio [17, 29, 36]. However, ruminal biohydrogenation $(\mathrm{BH})$ is very extensive for C18:3 [10, 19], which is isomerised to conjugated $\mathrm{C} 18: 3$, then hydrogenated to nonconjugated cis,trans-C18:2 [14, 18], subsequently to $\mathrm{C} 18: 1 \mathrm{FA}$ and finally to C18:0 [35].

The effects of several methods of treatment of oilseeds on the flow of unsaturated FA to the intestine have been studied: chemical treatment [8], extrusion $[6,7,30]$, roasting [30], or steam treating [12]. In the feed industry, extrusion is often preceded by preconditioning, which consists of preheating and premoistening a raw material by mixing it with steam and water for adjustment of moisture content [3]. To our knowledge, the single effects of this treatment have not been investigated.
The objectives of this work were to examine the impact of preconditioning or extrusion of linseed, focusing on the extent of BH, cis-9,trans-11C18:2 and trans-C18:1 isomers.

\section{MATERIALS AND METHODS}

\subsection{Treatments of linseed}

The linseed investigated was a commercial blend of $70 \%$ linseed and 30\% wheat bran, and linseed will designate this blend. Three forms of linseed were compared: raw linseed crushed through a $3 \mathrm{~mm}$ screen (RL), linseed crushed through a $6 \mathrm{~mm}$ screen and preconditioned at $35{ }^{\circ} \mathrm{C}(\mathrm{CL})$, linseed crushed through a $3 \mathrm{~mm}$ screen, preconditioned at $50{ }^{\circ} \mathrm{C}$, and extruded at $120{ }^{\circ} \mathrm{C}(\mathrm{EL})$. The composition of linseed is in Table I.

\subsection{Experimental procedure}

Three dry Holstein cows, fitted with ruminal and duodenal cannulas, were utilised. The diet was based on hay, soybean meal and 1 of the 3 forms of linseed, which supplied $86.1 \%$ of total FA with 18 carbon atoms in the diets. The amount distributed per cow, chemical composition 
Table I. Chemical composition of diet ingredients.

\begin{tabular}{lccccc}
\hline Ingredients & $\mathrm{RL}^{1}$ & $\mathrm{CL}^{1}$ & $\mathrm{EL}^{1}$ & $\mathrm{Hay}^{2}$ & Soybean meal \\
\hline $\mathrm{DM}(\%)$ & 92.3 & \multicolumn{6}{c}{89.3} & 93.5 & 92.0 & 89.1 \\
\hline \multicolumn{7}{c}{ (\% of DM) } \\
CP & 20.8 & 21.7 & 21.0 & 8.6 & 47.4 \\
NDF & 30.8 & 33.1 & 32.5 & 65.7 & 16.3 \\
ADF & 14.5 & 13.6 & 13.2 & 34.4 & 11.3 \\
Total C18 & 25.1 & 24.3 & 25.9 & 1.0 & 2.1 \\
\hline & \multicolumn{7}{c}{ \% of total C18) } \\
C18:0 & 3.5 & 3.3 & 3.5 & 3.7 & 5.0 \\
C18:1 & 18.0 & 16.6 & 18.1 & 10.5 & 18.3 \\
C18:2 & 19.1 & 19.8 & 19.2 & 20.6 & 61.4 \\
C18:3 & 58.1 & 59.1 & 57.9 & 59.5 & 11.8 \\
\hline
\end{tabular}

${ }^{1}$ RL: raw linseed; CL: preconditioned linseed; EL: extruded linseed.

${ }^{2}$ Hay composed of Dactylis glomerata and Festuca arundinacea.

${ }^{3}$ Fatty acids with 18 carbon atoms.

of the diets and diet ingredients are presented in Tables I and II. The cows were housed in individual tie stalls, meals were at 08:00 and 18:00 h, and water was available ad libitum. The treatments were carried out in a $3 \times 3$ Latin square with 3 periods of 3 weeks. During the last 3 days of each period, rumen and duodenal samples were collected at 08:00, 14:00 and 20:00 h in the first day, 02:00, 06:00, 12:00, 18:00 and 24:00 $\mathrm{h}$ in the second day, and 10:00, 16:00, 22:00 and 04:00 $\mathrm{h}$ in the third day, this schedule representing a sample every 2 hours over a period of 24 hours. Rumen content was taken from the cows by a vacuum pump, and was strained through a metal sieve $(0.25 \mathrm{~mm})$ to separate rumen fluid and rumen particle phase. The samples were immediately frozen and kept at $-18^{\circ} \mathrm{C}$ until analysis.

\subsection{Analytical procedures}

Ruminal and duodenal samples were freeze-dried (Vitris Freezemobile 25; Vitris Gardiner, NY), and subsequently ground in a ball mill (Dangoumau, distributed by Prolabo, Nogent-sur-Marne,
Table II. Ingredient and proximate chemical composition of the diets.

\begin{tabular}{lccc}
\hline Diets with & $\mathrm{RL}^{1}$ & $\mathrm{CL}^{1}$ & $\mathrm{EL}^{1}$ \\
\hline Amount $\left(\mathrm{kg} \mathrm{DM} \cdot \mathrm{d}^{-1}\right)$ & & & \\
Hay $^{2}$ & 9.20 & 9.20 & 9.20 \\
Soybean meal & 0.89 & 0.89 & 0.89 \\
Raw linseed & 2.77 & - & - \\
Preconditioned linseed & - & 2.68 & - \\
Extruded linseed & - & - & 2.80 \\
Mineral-vitamin mix & 0.085 & 0.085 & 0.085
\end{tabular}

Chemical composition (\% of dry matter)

\begin{tabular}{lccc} 
CP & 13.8 & 13.9 & 13.9 \\
NDF & 54.5 & 55.1 & 54.8 \\
ADF & 28.4 & 28.3 & 28.1 \\
Total C18 & 6.3 & 6.0 & 6.5 \\
\hline
\end{tabular}

${ }^{1}$ Diet with RL: raw linseed; CL: preconditioned linseed; or EL: extruded linseed.

${ }^{2}$ Hay composed of Dactylis glomerata and Festuca arundinacea.

${ }^{3}$ Complex containing 2\% Ca, 7\% P, 6\% Mg, $1 \% \mathrm{Na}, 300000 \mathrm{IU}$ per kg vitamin A, $60000 \mathrm{IU}$ per $\mathrm{kg}$ vitamin D3, $700 \mathrm{mg}$ per $\mathrm{kg}$ vitamin $\mathrm{E}$, and a blend of trace-elements. 
France). Different forms of linseed and diet ingredients were sampled during each period and analysed for DM, crude protein, neutral detergent fibre, acid detergent fibre, and FA composition [2,34].

Fatty acids in the samples were extracted and converted to methyl esters in one step, using sodium methoxide followed by boron trifluoride as described by Park and Goins [23]. This method allows a complete recovery of the main CLA isomers [11]. As mentioned by Precht and Molkentin [27], determination of trans-C18:1 isomers by GLC without a preliminary separation does not allow an exact quantification of trans-13C18:1,trans-14C18:1, and trans15C18:1 due to overlap of cis-9C18:1. Hence, one part of the FA methyl esters of each sample was fractionated by argentation TLC (plates $20 \times 20 \mathrm{~cm}$, Silica gel 60, Merk KGaA, Germany) as described by Le Doux et al. [15].

Total and trans-C18:1 FA were analysed by GLC (Agilent 6890N, equipped with a model 7683 auto injector, Network GC System, Palo alto, California, USA). The column was a fused silica capillary (CPSil88, $100 \mathrm{~m} \times 0.25 \mathrm{~mm}$ ID, Chrompack-Varian, Middleburg, Netherlands). The flame ionisation detector temperature was maintained at $260{ }^{\circ} \mathrm{C}$ and the injector at $255{ }^{\circ} \mathrm{C}$ with a split ratio of 1:50. Helium was the carrier gas with constant pressure (24.6 psi). The samples were injected in $0.5 \mathrm{~mL}$ of hexane. The initial temperature of the oven was $70{ }^{\circ} \mathrm{C}$, held for $1 \mathrm{~min}$, increased by $5{ }^{\circ} \mathrm{C} \cdot \mathrm{min}^{-1}$ to $100{ }^{\circ} \mathrm{C}$, held at $100{ }^{\circ} \mathrm{C}$ for $2 \mathrm{~min}$, increased by $10^{\circ} \mathrm{C} \cdot \mathrm{min}^{-1}$ to $175^{\circ} \mathrm{C}$, held at $175^{\circ} \mathrm{C}$ for $40 \mathrm{~min}$, increased by $5^{\circ} \mathrm{C} \cdot \mathrm{min}^{-1}$ to a final temperature of $225{ }^{\circ} \mathrm{C}$ and maintained at $225{ }^{\circ} \mathrm{C}$ for $15 \mathrm{~min}$, as described by Loor et al. [16]. The identification and quantification of peaks was made by comparison with commercial standards when available (Sigma, St. Louis, USA). The standards were used for trans-9, trans-
10 and trans-11C18:1, but the identification of trans-4 to trans-8C18:1 and trans12 to trans-16C18:1 was made by comparison with published chromatograms [28]. Trans-10C18:1 and trans-11C18:1 were not completely separated, and were considered together and designated as trans$10+11 \mathrm{C} 18: 1$. They were used as an internal standard to quantify trans-C18:1 FA determined by Ag-TLC.

\subsection{Calculations and statistical analysis}

Ruminal apparent $\mathrm{BH}$ of $\mathrm{C} 18: 2$ and C18:3 in duodenal flow and the different rumen phases was calculated using the following formula: $\mathrm{BH}=100-100 \times$ (individual unsaturated $\mathrm{C} 18$ / total $\mathrm{C} 18$ in samples) / (individual unsaturated C18 / total C18 in the diet) [37].

The differences between linseed treatments and digesta types were assessed by analysis of variance using the general linear model of SYSTAT (version 9, SPPS Inc., 1998 Chicago). The model used was:

$$
\mathrm{Y}_{i j k l}=\mu+\mathrm{L}_{i}+\mathrm{C}_{j}+\mathrm{P}_{k}+\mathrm{S}_{l}+\mathrm{LS}_{i l}+\varepsilon_{i j k l}
$$

where $\mathrm{Y}$ are the individual values for dependent variables, $\mu$ is the overall mean, $\mathrm{L}$ is the effect of the form of linseed, $\mathrm{C}$ is the cow effect, $\mathrm{P}$ is the period effect, $\mathrm{S}$ is the effect of digesta type, and LS is the effect of the form of linseed $\times$ digesta type interaction. A Tukey pairwise comparison test was used to compare the different forms of linseed or digesta types. The differences were declared significant at $P<0.05$.

\section{RESULTS AND DISCUSSION}

The proportions of FA in the duodenum, the rumen fluid and the rumen particle phase are shown in Table III. 


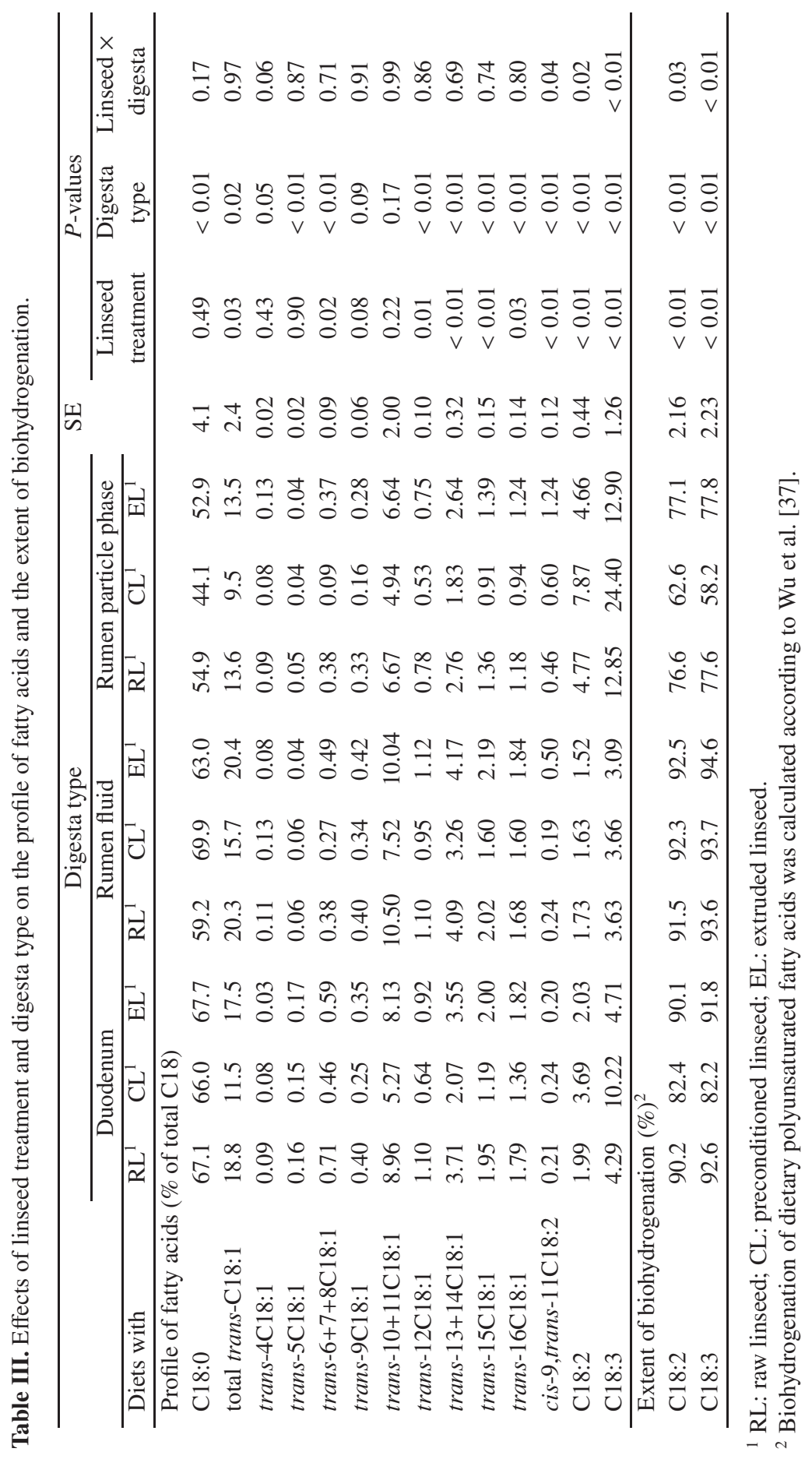




\subsection{Effects of linseed treatments on apparent biohydrogenation of polyunsaturated fatty acids}

The FA profile in the duodenal flow indicated that $\mathrm{C} 18: 2$ and $\mathrm{C} 18: 3 \mathrm{BH}$ were high, as previously observed with raw linseed in vivo [31] or with $\left({ }^{14} \mathrm{C}\right)$ linoleic and $\left({ }^{14} \mathrm{C}\right)$ linolenic acids in vitro [35]. $\mathrm{CL}$ resulted in a higher proportion and hence lower apparent $\mathrm{BH}$ of both $\mathrm{C} 18: 2$ and C18:3. To our knowledge, the effect of preconditioning without extrusion on $\mathrm{BH}$ of unsaturated FA, at the low temperature utilised in our experiment, has not been studied. Although the increased temperature during the premoistening process might provoke partial protection of PUFA against $\mathrm{BH}[21,25]$, it is unlikely that this explains the higher PUFA proportion in the digesta of cows fed CL in the current experiment because of the low preconditioning temperature and the reduced PUFA proportion in the digesta of animals fed EL, which was pretreated at a higher temperature. Current differences between CL, RL and EL were most probably due to the higher particle size of CL compared to the other linseed forms. The effects of oilseed particle size on ruminal $\mathrm{BH}$ have not been extensively studied, but a comparison between whole and ground seeds did not show significant differences on duodenal flow of PUFA from soybeans [32]. On the contrary, Pires et al. [26] mentioned that $\mathrm{BH}$ tended to be lower with ground than with whole cottonseed, and hypothesised that grinding could result in a lower residence time in the rumen, which could reduce $\mathrm{BH}$ extent. Indeed, a potential protective effect against rumen $\mathrm{BH}$ of preconditioning cannot be concluded from the current experiment and would need further experiments, specially designed, with different preconditioning temperatures, and similar particle size among treatments.

In our experiment, extrusion of linseed did not affect the BH of PUFA calcu- lated from the FA profile in duodenal flow, rumen fluid or rumen particle phase. Several previous reports mentioned that extrusion does not protect PUFA from canola in vitro [13], from linseed or canola in situ [7, 13] or from soybeans in vivo [6]. On the contrary, others mentioned a decreased $\mathrm{BH}$ with rapeseeds in vivo [4] or with soybeans in vitro [30] or in situ [6]. Extrusion temperature was low in the present experiment, as opposed to the temperatures over $140{ }^{\circ} \mathrm{C}$ used in experiments showing a decreased $\mathrm{BH}[4,30]$. However, increasing extrusion temperature from $120{ }^{\circ} \mathrm{C}$ to $140{ }^{\circ} \mathrm{C}$ has only minor effects on PUFA proportions in ruminal bags or milk fat [6].

\subsection{Biohydrogenation intermediates}

The proportion of cis-9,trans-11C18:2 was low in rumen phases and the duodenum in our experiment. Similarly, the addition of linseed oil only resulted in a minor increase in cis-9,trans-11C18:2 in the duodenal flow [18], and this FA probably originated from the C18:2 of linseed. In the duodenum, trans-10+11C18:1 represented $48.1,45.9$ and $46.3 \%$ of total trans-C18:1 with RL, CL and EL, respectively, and were the most important isomers followed by trans-13+14C18:1. Trans-15-C18:1 and trans-16-C18:1 were also important $\mathrm{BH}$ intermediates in agreement with the results obtained by Loor et al. [18] with linseed oil. Similar patterns were observed in rumen samples.

In the rumen, extrusion of linseed resulted in twice higher proportions of cis-9,trans-11C18:2 than RL or CL. Chouinard et al. [5] observed 3 times higher proportions of cis-9,trans-11C18:2 in milk with dietary addition of extruded compared with raw soybeans. In vitro, the extrusion of canola strongly increased the proportion of cis-9,trans-11C18:2 [13]. The lower effect in the present experiment could be explained by an inhibition of the 
isomerisation of C18:2 by high amounts of C18:3 provided by linseed [33].

Amongst all digesta types, CL resulted in lower proportions of total trans-C18:1, trans $-6+7+8 \mathrm{C} 18: 1$ and trans-12 to trans16C18:1 intermediates, but trans-9 and trans-10+11C18:1 were not significantly affected by linseed treatments. These lower proportions of trans-C18:1 with CL are consistent with the lower PUFA disappearance.

Compared with RL, EL did not affect trans-C18:1 FA. An increased trans$11 \mathrm{C} 18: 1$ proportion in response to extrusion has been mentioned in situ with soybeans [6] or canola [13], and in vivo with soybeans [6]. The effect of extrusion on trans-C18:1 and cis-9,trans-11C18:2 could be due to higher concentrations of free oil, available for isomerisation, resulting in an accumulation of trans intermediates because of the limited capacity of the two reduction steps of BH of C18:2 [33]. In our experiment, we observed a high accumulation of trans-10+11C18:1 in the ruminal and duodenal contents of the cow consuming RL during the first period, which resulted in a high variability and could have masked a possible effect of extrusion.

\subsection{Effect of digesta type}

The different digesta types resulted in different estimates of the $\mathrm{BH}$ extent or proportions of $\mathrm{BH}$ intermediates. The evaluation of the duodenal FA profile is the reference method to estimate rumen BH. Compared with duodenal flow, ruminal fluid contained lower proportions of PUFA. Opposite differences were observed in the rumen particle phase. Higher PUFA proportions in the rumen particle phase could be partly due to undigested feedstuff within this digesta type when sampling little after the meal [35]. Moreover, because fat inside particles is less accessible to rumen bacteria than in the ru- men fluid, a slower BH could explain the higher proportion of the first intermediate of BH (cis-9,trans-11C18:2) and the lower proportions of later intermediates (trans$\mathrm{C} 18: 1$ ) or final $\mathrm{BH}$ products (predominantly $\mathrm{C} 18: 0$ ).

The significant interaction between digesta type and linseed treatment for several FA indicates some differences between linseed treatments only to be apparent in specific digesta types: e.g. preconditioning and grinding to a higher particle size increased C18:2 and C18:3 proportions in the duodenum and the ruminal particle phase, but not in the rumen fluid, whereas extrusion increased rumen cis-9,trans-11C18:2 but not duodenal proportions.

Except for cis-9,trans-11C18:2, the results obtained from duodenal samples were intermediate between the results from the rumen fluid and the rumen particle phase, suggesting that a representative sample of these two ruminal phases could be accurate for studying $\mathrm{BH}$. The proportion of cis-9,trans-11C18:2 in the duodenum was similar to that in the rumen fluid and much lower than in the rumen particle phase. This low proportion could relate to the fact that ruminal cis-9,trans-11C18:2 is mainly in protozoa [9], which sequesters in the rumen [1]. However, this role of protozoa cannot explain why differences between ruminal and duodenal cis-9,trans-11C18:2 were more important with EL, because due to free oil, extrusion is rather expected to reduce protozoa numbers [20].

\section{CONCLUSIONS}

Our results showed that BH of PUFA from linseed results in a low proportion of cis-9,trans-11C18:2, and that trans-10+11 to trans-16C18:1 are important $\mathrm{BH}$ intermediates. Compared to 3-mm screen ground raw linseed, 6-mm screen ground and preconditioned linseed exhibited a partial protection of PUFA from rumen $\mathrm{BH}$ 
and lower proportions of trans-C18:1, especially trans-12 to trans-16C18:1. Extrusion did not result in significant modifications of the extent of $\mathrm{BH}$, and increased the proportion of cis-9,trans-11C18:2 in the rumen but not in the duodenal flow. For most FA, the results obtained with the duodenal flow were intermediate between the results obtained from liquid and particle phases of the rumen.

\section{REFERENCES}

[1] Ankrah P., Loerch P.S., Dehority B.A., Sequestration, migration and lysis of protozoa in the rumen, J. Gen. Microbiol. 136 (1990) 1869-1875.

[2] AOAC (Association of Official Analytical Chemists), Official Methods of Analysis, 16th ed., AOAC, Gaithersburg, MA, 1996.

[3] Bouvier J.M., Engineering analysis of preconditioning in the extrusion-cooking process, Cereal Foods World 41 (1996) 737740.

[4] Chapoutot P., Sauvant D., Nutritive value of raw and extruded pea-rapeseed blends for ruminants, Anim. Feed Sci. Technol. 65 (1997) 59-77.

[5] Chouinard P.Y., Corneau L., Butter W.R., Bauman D.E., Chilliard Y., Drackley J.K., Effect of dietary lipid source on conjugated linoleic acid concentrations in milk fat, J. Dairy Sci. 84 (2001) 680-690.

[6] Chouinard P.Y., Lévesque J., Girard V., Brisson J., Dietary soybeans extruded at different temperatures: milk composition and in situ fatty acid reactions, J. Dairy Sci. 80 (1997) 2913-2925.

[7] Clinquart A., Istasse L., Van Eenaeme C., Diez M., Dufrasne I., Bienfait J.M., Influence de l'extrusion de mélanges de graines de lin et d'orge, de graines de pois et de colza, et de fèves de soja, sur la dégradabilité dans le rumen de leurs fractions azotée et lipidique et sur leur composition en acides gras, Ann. Zootech. 42 (1993) 130-131.

[8] Cook J.L., Scott T.W., Ferguson K.A., McDonald I.W., Production of polyunsaturated ruminant fats, Nature 228 (1970) 178-179.

[9] Devillard E., McIntosh F.M., Young K., Castet M., Wallace R.J., Newbold C.J.,
Conjugated linoleic acid composition of rumen bacterial and protozoal populations, Reprod. Nutr. Dev. 44 (2004) S60.

[10] Doreau M., Chilliard Y., Digestion and metabolism of dietary fat in farm animals, Brit. J. Nutr. 78 (1997) S15-S35.

[11] Duckett S.K., Andrae J.G., Owens F.N., Effects of high oil corn or added corn oil on ruminal biohydrogenation of fatty acids and conjugated linoleic acid formation in beef steers fed finishing diets, J. Anim. Sci. 80 (2002) 3353-3360.

[12] Dufrasne I., Gielen M., Istasse L., Van Eenaeme C., Gabriel A., Clinquart A., Bienfait J.M., Effet de l'incorporation de graines de lin floconnées sur support d'orge chez le taurillon à l'engraissement, Ann. Zootech. 40 (1991) 9-18.

[13] Enjalbert F., Eynard P., Nicot M.C., Troegeler-Meynadier A., Bayourthe C., Moncoulon R., In vitro versus in situ ruminal biohydrogenation of unsaturated fatty acids from a raw or extruded mixture of ground canola seed/canola meal, J. Dairy Sci. 86 (2003) 351-359.

[14] Kepler C.R., Tove S.B., Biohydrogenation of unsaturated fatty acids. III. purification and properties of a linoleate $\Delta 12$-cis $\Delta 11$ trans isomerase from Butyrivibrio fibrisolvens, J. Biol. Chem. 242 (1967) 5686-5692.

[15] Le Doux M., Rouzeau A., Bas P., Sauvant D., Occurrence of trans-C18:1 fatty acid isomers in goat milk: effect of two dietary regimens, J. Dairy Sci. 85 (2002) 190-197.

[16] Loor J.J., Bandara A.B.P.A., Herbein J.H., Characterization of 18:1 and 18:2 isomers produced during microbial biohydrogenation of unsaturated fatty acids from canola and soybean oil in rumen of lactating cows, J. Anim. Physiol. An. N. 86 (2002) 422-432.

[17] Loor J.J., Ferlay A., Ollier A., Doreau M., Chilliard Y., Relationship among trans and conjugated fatty acids and bovine milk fat yield due to dietary concentrate and linseed oil, J. Dairy Sci. 88 (2005) 726-740.

[18] Loor J.J., Ueda K., Ferlay A., Chilliard Y., Doreau M., Biohydrogenation, duodenal flow, and intestinal digestibility of trans fatty acids and conjugated linoleic acids in response to dietary forage:concentrate ratio and linseed oil in dairy cows, J. Dairy Sci. 87 (2004) 2472-2485.

[19] Loor J.J., Ueda K., Ferlay A., Chilliard Y., Doreau M., Intestinal flow and digestibility of trans fatty acids and conjugated linoleic 
acids (CLA) in dairy cows fed a highconcentrate diet supplemented with fish oil, linseed oil or sunflower oil, Anim. Feed Sci. Tech. 119 (2005) 203-225.

[20] Mohamed O.E., Satter L.D., Grummer R.R., Ehle F.R., Influence of dietary cottonseed and soybean on milk production and composition, J. Dairy Sci. 71 (1988) 2677-2688.

[21] Mustafa A., Chouinard Y.P., Ouellet D.R., Soita H., Effect of moist heat treatment on ruminal nutrient degradability of sunflower seed, J. Sci. Food Agr. 83 (2003) 1059-1064.

[22] Palmquist D.L., Jenkins T.C., Fat in lactation rations: review, J. Dairy Sci. 63 (1980) 1-14.

[23] Park P.W., Goins R.E., In situ preparation of fatty acid methyl esters for analysis of fatty acid composition in foods, J. Food Sci. 59 (1994) 1262-1266.

[24] Parodi P.W., Conjugated linoleic acid and other anticarcinogenic agents of bovine milk fat, J. Dairy Sci. 82 (1999) 1339-1349.

[25] Petit H.V., Tremblay G.F., Tremblay E., Nadeau P., Ruminal biohydrogenation of fatty acids, protein degradability, and dry matter digestibility of flax seed treated with different sugar and heat combinations, Can. J. Anim. Sci. 82 (2002) 241-250.

[26] Pires A.V., Eastridge M.L., Firkins J.L., Lin Y.C., Effects of heat treatment and physical processing on nutrient digestibility and production performance by lactating cows, J. Dairy Sci. 80 (1997) 1685-1694.

[27] Precht D., Molkentin J., Rapid analysis of the isomers of trans-octadecenoic acid in milk fat, Int. Dairy J. 6 (1996) 791-809.

[28] Precht D., Molkentin J., C18:1, C18:2 and C18:3 trans and cis fatty acid isomers including conjugated $\operatorname{cis} \Delta 9$, trans $\Delta 11$ linoleic acid (CLA) as well as total fat composition of German human milk lipids, Nahrung 43 (1999) 233-244.
[29] Raes K., Haak L., Balcaen A., Claeys E., Demeyer D., De Smet S., Effect of linseed feeding at similar linoleic acid levels on the fatty acid composition of doublemuscled Belgian blue young bulls, Meat Sci. 66 (2004) 307-315.

[30] Reddy P.V., Morrill J.L., Nagaraja T.G., Release of free fatty acids from raw or processed soybeans and subsequent effects on fiber digestibilities, J. Dairy Sci. 77 (1994) 3410-3416.

[31] Scollan N.D., Dhanoa M.S., Choi N.J., Maeng W.J., Enser M., Biohydrogenation and digestion of long chain fatty acids in steers fed on different sources of lipid, J. Agric. Sci. (Camb.) 136 (2001) 345-355.

[32] Tice E.M., Eastridge M.L., Firkins J.L., Raw soybeans and roasted soybeans of different particle sizes. 2. Fatty acid utilization by lactating cows, J. Dairy Sci. 77 (1994) 166-180.

[33] Troegeler-Meynadier A., Nicot M.C., Bayourthe C., Moncoulon R., Enjalbert F., Effect of $\mathrm{pH}$ and concentration of linoleic and linolenic acids on extent and intermediates of ruminal biohydrogenation in vitro, $\mathrm{J}$. Dairy Sci. 86 (2004) 4054-4063.

[34] Van Soest P.J., Robertson J.B., Lewis B.A., Methods for dietary fiber, neutral detergent fiber, and nonstarch polysaccharides in relation to animal nutrition, J. Dairy Sci. 74 (1991) 3583-3597.

[35] Ward P.F.V., Scott T.W., Dawson R.M.C., The hydrogenation of unsaturated fatty acid in the ovine digestive tract, Biochem. J. 92 (1964) 60-68.

[36] Williams C.M., Dietary fatty acids and human health: review, Ann. Zootech. 49 (2000) 165-180.

[37] Wu Z., Ohajuruka O.A., Palmquist D.L., Ruminal synthesis, biohydrogenation and digestibility of fatty acids by dairy cows, J. Dairy Sci. 74 (1991) 3025-3034 A.

To access this journal online: www.edpsciences.org 